\title{
Status i potrzeby leczenia protetycznego braków zębowych u osób w wieku 65-74 lat w województwie zachodniopomorskim w zależności od źródła finansowania*
}

\author{
Comparing prosthetic status and need for prosthetic treatment of tooth loss in patients aged \\ 65-74 years in the Western Pomerania Region depending on the source of financing
}

\author{
Łukasz Wilczyński ${ }^{凶}$ \\ Pomorski Uniwersytet Medyczny w Szczecinie, Zakład Periodontologii, al. Powstańców Wlkp. 72, 70-111 Szczecin \\ $\triangle 7$ wilczynski@gmail.com
}

\begin{abstract}
Introduction: According to demographic predictions, the number of people aged 65 years and more on a global scale will reach one billion in 2030. Understanding the epidemiology of prosthetic status and need for prosthetic treatment of tooth loss in the elderly population is essential to determine risk factors for tooth loss, prepare comprehensive dental treatment, and to develop appropriate prevention programmes.

The purpose of this study was to compare the prosthetic status and prosthetic treatment in edentulous patients depending on the source of financing of dental treatment.

Materials and methods: The study was conducted in a group of 294 people ( 163 women and 131 men) aged 65-74 years living in West Pomerania province in Poland. The clinical examination assessed the number of preserved teeth, the average number of DMF and its components, the number of preserved short-circuit supporting areas using a modified classification of missing teeth by Eichner, the status of prosthetic treatment, and the need for prosthetic treatment according to World Health Organization (Geneva, 1997). Findings were compared with the source of financing of dental treatment.
\end{abstract}

\begin{abstract}
ABSTRAKT
Wstęp: Według prognoz demograficznych liczba osób w wieku 65 lat i powyżej w skali globalnej osiągnie w 2030 r. miliard. Wiedza na temat epidemiologii statusu protetycznego i potrzeb leczenia protetycznego w populacji osób starszych jest niezbędna do ustalenia czynników ryzyka utraty zębów, a także przygotowania kompleksowego leczenia stomatologicznego oraz stworzenia odpowiednich programów profilaktycznych dla tej grupy badanych.

Celem pracy było porównanie statusu protetycznego i potrzeb leczenia protetycznego braków zębowych u osób starszych w zależności od źródła finansowania ich leczenia stomatologicznego.

Materiały i metody: Badanie przeprowadzono na grupie 294 osób (163 kobiety i 131 mężczyzn) w wieku 65-74 lat, mieszkających na terenie województwa zachodniopomorskiego. W badaniu klinicznym oceniono liczbę zachowanych zębów, średnią liczbę
\end{abstract}

Results: The study found that among respondents using only dental services under the National Health Fund compared to those who use only the services of private dental offices there was: a higher percentage of edentulous people (27.4\% vs. $2.06 \%)$, a lower percentage of people with preserved functional dentition (15.07\% vs. $49.48 \%$ ), a higher mean number of teeth removed (18.14 vs. 9.73), a higher percentage of people who do not have support zones ( $45.21 \%$ vs. $10.31 \%$ ), a lower percentage of people using a complement fixed in the jaw (5.48\% vs. $29.9 \%$ ) and in the mandible ( $1.37 \%$ vs. $17.53 \%$ ), a higher percentage of people using a full prosthesis in the jaw ( $34.25 \%$ vs. $4.12 \%$ ) and in the mandible (23.29\% vs. $3.09 \%$ ), a lower percentage of people using a partial denture and prosthetic bridge or bridges in the jaw (1.37\% vs. $10.31 \%$ ) and in the mandible ( $0.00 \%$ vs. $4.12 \%$ ), and a higher percentage of people who required a dental prosthesis fixed in the jaw (23.29\% vs. $2.06 \%$ ) and in the mandible (20.55\% vs. $3.09 \%)$. Conclusion: The study revealed a significantly lower oral health status among respondents using only services within the National Health Fund.

Keywords: dentition; old age; epidemiology; edentulousness; dental prosthetics.

PUW i jej składowe, liczbę zachowanych stref podparcia na podstawie zmodyfikowanej klasyfikacji wg Eichnera, status protetyczny oraz potrzeby leczenia protetycznego braków zębowych wg klasyfikacji WHO (Genewa, 1997). Uzyskane dane porównano ze źródłem finansowania leczenia stomatologicznego badanych. Wyniki: Wśród badanych korzystających wyłącznie z usług stomatologicznych w ramach Narodowego Funduszu Zdrowia (NFZ), w porównaniu do osób korzystających tylko z usług stomatologicznych gabinetów prywatnych, stwierdzono: wyższy odsetek osób bezzębnych ( $27,4 \%$ vs 2,06\%), niższy odsetek osób z zachowanym funkcjonalnym uzębieniem (15,07\% vs 49,48\%), wyższą średnią liczbę zębów usuniętych (18,14\% vs 9,73\%), wyższy odsetek osób nieposiadających stref podparcia $(45,21 \%$ vs 10,31\%), niższy odsetek osób użytkujących uzupełnienia stałe w szczęce ( $5,48 \%$ vs $29,9 \%$ ) i w żuchwie $(1,37 \%$ vs $17,53 \%)$, wyższy odsetek osób użytkujących protezę całkowitą w szczęce $(34,25 \%$ vs $4,12 \%)$ i w żuchwie $(23,29 \%$ vs 3,09\%), wyższy odsetek osób

* Zwięzła wersja rozprawy doktorskiej przyjętej przez Radę Wydziału Lekarsko-Stomatologicznego Pomorskiego Uniwersytetu Medycznego w Szczecinie. Promotor dr hab. n. med., prof. PUM Elżbieta Dembowska. Oryginał obejmuje: 197 stron, 75 tabel, 4 ryciny i 149 pozycji piśmiennictwa 
wymagających uzupełnienia protetycznego bezzębia w szczęce $(23,29 \%$ vs $2,06 \%)$ i w żuchwie $(20,55 \%$ vs $3,09 \%)$.

Wniosek: W badaniu stwierdzono istotnie gorszy stan zdrowia jamy ustnej u pacjentów deklarujących korzystanie wyłącznie z usług stomatologicznych w ramach świadczeń gwarantowanych NFZ.

Słowa kluczowe: uzębienie; starość; epidemiologia; bezzębie; protetyka stomatologiczna.

\section{WSTĘP}

Osoby w wieku starszym stanowią coraz większą część społeczeństwa. W ciągu ostatnich 20 lat obserwuje się spadek liczby zgonów oraz wydłużenie długości życia ludzi w Polsce. Według danych Głównego Urzędu Statystycznego (GUS) średnia długość życia mężczyzn w Polsce wynosiła w 2012 r. 72,7 lat, a kobiet 81 lat. W porównaniu do danych z 1990 r. długość życia mężczyzn wydłużyła się o 6,5 roku, a kobiet o 5,8 lat [1]. Prognozy na kolejne lata wykazują tendencję do spadku ogólnej liczby ludności w Polsce oraz wzrostu liczby osób w wieku starszym. Według prognoz GUS w 2015 r. osoby powyżej 60. r.ż. miały stanowić 19,41\% ogólnej liczby ludności w Polsce, w 2020 r. mają stanowić $22,12 \%$, a w 2035 r. - 26,73\% populacji polskiej [2]. Prognozy te świadczą o starzeniu się polskiego społeczeństwa. Podobne tendencje występują także w krajach Europy Zachodniej. Zgodnie z prognozami Europejskiego Urzędu Statystycznego - Eurostat (2011) odsetek osób w wieku 65 lat i powyżej w Polsce wyniesie 35\% w 2060 r. W 2010 r. na jedną osobę w wieku 65 lat i powyżej przypadały 4 młodsze osoby. W 2060 r. powyższy stosunek zmieni wartość na 1:2 [3]. Według prognoz w 2030 r. liczba osób w wieku 65 lat i powyżej w skali globalnej osiągnie miliard [4].

Zjawisko starzenia się społeczeństwa związane jest nie tylko z rozwojem nowych technologii medycznych, nowoczesnych metod diagnostycznych, ogólnym rozwojem cywilizacyjnym, propagowaniem zachowań prozdrowotnych, wzrostem jakości warunków życia społeczeństwa, zamożności $[1,5]$, ale również z czynnikami związanymi z ograniczeniem prokreacji na skutek wydłużenia okresu edukacji, przewagi konsumpcyjnego modelu życia oraz rosnącej roli kariery zawodowej [6].

Uwzględniając powyższe prognozy demograficzne, szczególnego znaczenia nabiera prawidłowa opieka nad osobami starszymi, również ta stomatologiczna. Koniecznym staje się zapoznanie z odmiennościami problemów stomatologicznych oraz możliwościami ich rozwiązywania w grupie pacjentów starszych [7]. Możliwości kompleksowego, bezpłatnego leczenia w Polsce są obecnie bardzo ograniczone.

Jednak osoby w podeszłym wieku stanowią grupę priorytetową działań dla Światowej Organizacji Zdrowia (WHO) w zakresie zdrowia jamy ustnej. W 2007 r. WHO rozpoczęła globalny przegląd potrzeb profilaktyczno-leczniczych oraz ocenę stanu zdrowia jamy ustnej osób starszych, zwracając uwagę na ograniczenia związane z opieką stomatologiczną. Stwierdzono, że dostępność do aktualnych informacji epidemiologicznych o stanie zdrowia jamy ustnej, zachowaniach prozdrowotnych oraz pracy służby zdrowia umożliwia stworzenie nowych oraz rozwój istniejących już programów profilaktycznych i leczniczych w grupie osób starszych. W wytycznych podkreślano, że niezbędne jest przeprowadzenie szkoleń służby zdrowia, również podstawowej opieki zdrowotnej w zakresie ochrony zdrowia jamy ustnej osób starszych, a promocja zdrowia jamy ustnej powinna stanowić integralną część podstawowej opieki zdrowotnej. Nabycie wiedzy dotyczącej procesów fizjologicznych, objawów chorób ogólnoustrojowych oraz kompleksowego leczenia starszych pacjentów stanowi podstawę sukcesu opieki nad pacjentami w tej grupie wiekowej. Za słuszne uznano włączenie opiekunów domowych oraz pracowników domów pomocy społecznej zajmujących się osobami starszymi do aktywnej pomocy w zakresie utrzymania prawidłowego zdrowia jamy ustnej. Zwrócono również uwagę na bariery finansowe osób starszych utrzymujących się często wyłącznie ze świadczeń emerytalnych. Możliwości kompleksowego leczenia stomatologicznego tych osób są bardzo ograniczone. Niewystarczające jest pokrycie kosztów ochrony zdrowia jamy ustnej osób starszych ze środków publicznych [8].

Celem pracy było porównanie statusu protetycznego i potrzeb leczenia protetycznego braków zębowych w zależności od źródła finansowania leczenia stomatologicznego.

\section{MATERIAŁY I METODY}

Badania przeprowadzono na grupie 294 osób (163 kobiety i 131 mężczyzn) w wieku 65-74 lat, mieszkających na terenie województwa zachodniopomorskiego, równolegle do ogólnopolskich badań pt. „Ocena potrzeb profilaktyczno-leczniczych w wybranych grupach wiekowych populacji polskiej na podstawie występowania chorób przyzębia”. W województwie zachodniopomorskim zbadano mieszkańców Szczecina oraz mniejszych miast - Łobza i Polic. W badaniu klinicznym oceniono: liczbę zachowanych zębów, średnią liczbę PUW i jej składowe, liczbę zachowanych stref podparcia w oparciu o zmodyfikowaną klasyfikację braków zębowych wg Eichnera, status protetyczny oraz potrzeby leczenia protetycznego braków zębowych wg klasyfikacji WHO (Genewa, 1997). Na podstawie uzyskanych informacji dotyczących źródła finansowania leczenia stomatologicznego wyróżniono 3 grupy badanych osób:

1) badani korzystający wyłącznie z usług stomatologicznych w ramach Narodowego Funduszu Zdrowia (NFZ);

2) badani korzystający wyłącznie z usług stomatologicznych gabinetów prywatnych;

3) badani korzystający zarówno z usług stomatologicznych w ramach NFZ, jak i z usług gabinetów prywatnych.

Wyniki poddano analizie statystycznej za pomocą programu statystycznego STATA 11. Za różnice istotne statystycznie we wszystkich przeprowadzonych testach uznano te, dla których wartość prawdopodobieństwa p <0,05. 


\section{WYNIKI}

Najwyższy odsetek badanych $(42,18 \%)$ stwierdzono wśród osób korzystających zarówno z leczenia stomatologicznego w ramach NFZ, jak i gabinetów prywatnych (ryc. 1). Odnotowano 32,99\% osób korzystających wyłącznie z usług stomatologicznych gabinetów prywatnych oraz $24,83 \%$ badanych korzystających wyłącznie z usług stomatologicznych w ramach świadczeń gwarantowanych NFZ.

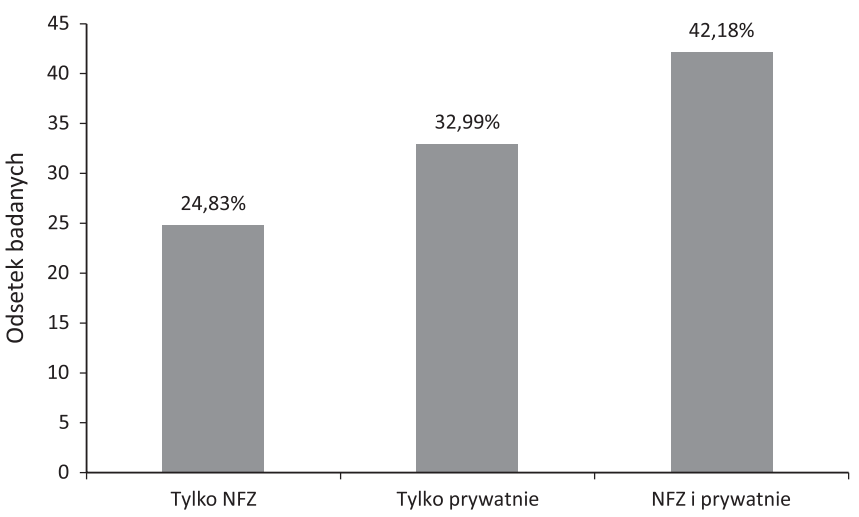

RYCINA 1. Podział badanych w zależności od źródła finansowania leczenia stomatologicznego

Spośród badanych korzystających wyłącznie z usług leczenia stomatologicznego $w$ ramach świadczeń gwarantowanych NFZ, w porównaniu do osób korzystających tylko z leczenia stomatologicznego $\mathrm{w}$ gabinetach prywatnych, stwierdzono znamiennie wyższą średnią liczbę zębów usuniętych $(18,14$ vs 9,73), niższą średnią liczbę zębów wypełnionych (3,74 vs $9,43)$ oraz wyższą średnią liczbę PUW $(22,86$ vs 20,06$)$. Stan uzębienia badanych korzystających wyłącznie z usług NFZ był zatem istotnie gorszy w porównaniu do badanych korzystających tylko z usług gabinetów prywatnych (tab. 1).

Najwyższy odsetek osób bezzębnych i mających tylko 1-6 zębów stwierdzono w grupie badanych korzystających wyłącznie z usług stomatologicznych w ramach NFZ, odpowiednio 27,40\% i 12,33\% (tab. 2). Najniższy odsetek osób bezzębnych i mających tylko 1-6 zębów odnotowano w grupie badanych korzystających wyłącznie z leczenia stomatologicznego w gabinetach prywatnych, odpowiednio 2,06\% i 3,09\%. Najwyższy odsetek badanych mających $\geq 20$ zębów własnych zaobserwowano w grupie osób korzystających wyłącznie z leczenia stomatologicznego w gabinetach prywatnych $(49,48 \%)$. Najniższy odsetek osób mających $\geq 20$ zębów własnych odnotowano w grupie badanych korzystających wyłącznie z usług stomatologicznych w ramach NFZ. Różnice te są istotne statystycznie $(p=0,000001)$.

Porównując liczbę zachowanych stref podparcia ze źródłem finansowania leczenia stomatologicznego, wykazano zależność istotną statystycznie $(\mathrm{p}=0,00009)$. Brak stref podparcia stwierdzono najczęściej u osób korzystających wyłącznie z usług leczenia stomatologicznego w ramach NFZ (33 osoby, 45,21\%) oraz najrzadziej wśród badanych korzystających wyłącznie z usług leczenia stomatologicznego w gabinetach prywatnych (10 osób, 10,31\%). Zachowanie wszystkich stref podparcia odnotowano u 46 (47,42\%) osób korzystających wyłącznie z usług gabinetów prywatnych i u $23(31,51 \%)$ korzystających wyłącznie z usług stomatologicznych w ramach NFZ. Najwyższy odsetek badanych korzystających wyłącznie z usług gabinetów prywatnych stanowiły osoby mające 4 strefy podparcia $(47,42 \%)$, podczas gdy najwyższy odsetek badanych korzystających z usług stomatologicznych w ramach NFZ stanowiły osoby bez stref podparcia $(45,21 \%)$ - tabela 3 .

Porównując status protetyczny wg klasyfikacji WHO w szczęce i w żuchwie oraz źródło finansowania leczenia stomatologicznego, wykazano zależność istotną statystycznie. Protezę całkowitą istotnie najczęściej odnotowano wśród osób korzystających wyłącznie z usług stomatologicznych w ramach NFZ w porównaniu do korzystających wyłącznie z usług gabinetów prywatnych i korzystających z usług stomatologicznych w ramach NFZ i gabinetów prywatnych zarówno

TABELA 1. Podział badanych ze względu na średnią liczbę $P, U, W$ i PUW oraz źródło finansowania leczenia stomatologicznego

\begin{tabular}{|c|c|c|c|c|c|c|c|c|c|}
\hline \multirow{2}{*}{\multicolumn{2}{|c|}{ Kategoryzacja }} & \multicolumn{2}{|c|}{ Średnia liczba P } & \multicolumn{2}{|c|}{ Średnia liczba U } & \multicolumn{2}{|c|}{ Średnia liczba W } & \multicolumn{2}{|c|}{ Średnia liczba PUW } \\
\hline & & wartość & $p$ & wartość & $p$ & wartość & $p$ & wartość & $p$ \\
\hline \multirow{2}{*}{$\begin{array}{l}\text { Źródło finansowania } \\
\text { leczenia stomatologicznego }\end{array}$} & wyłącznie NFZ & 0,99 & \multirow{2}{*}{0,1129} & 18,14 & \multirow{2}{*}{0,00001} & 3,74 & \multirow{2}{*}{0,00001} & 22,86 & \multirow{2}{*}{0,0023} \\
\hline & NFZ i prywatnie & 1,31 & & 12,75 & & 6,81 & & 20,88 & \\
\hline
\end{tabular}

TABELA 2. Podział badanych ze względu na liczbę zachowanych zębów i źródło finansowania leczenia stomatologicznego

\begin{tabular}{|c|c|c|c|c|c|c|c|c|}
\hline Kategc & ryzacja & $\begin{array}{l}\text { Pacjenci } \\
\text { bezzębni }\end{array}$ & $\begin{array}{l}\text { Pacjenci } \\
\text { mający } \\
\text { 1-6 zębów }\end{array}$ & $\begin{array}{c}\text { Pacjenci } \\
\text { mający } \\
\text { 7-19 zębów }\end{array}$ & $\begin{array}{l}\text { Pacjenci } \\
\text { mający } \\
\geq 20 \text { zębów }\end{array}$ & $x^{2}$ Pearsona & R rang & Spearman \\
\hline \multirow{2}{*}{$\begin{array}{l}\text { Źródło finansowania } \\
\text { leczenia } \\
\text { stomatologicznego }\end{array}$} & wyłącznie NFZ & $\begin{array}{c}20 \\
27,40 \%\end{array}$ & $\begin{array}{c}9 \\
12,33 \%\end{array}$ & $\begin{array}{c}33 \\
45,21 \%\end{array}$ & $\begin{array}{c}11 \\
15,07 \%\end{array}$ & \multirow[b]{2}{*}{$p=0,000001$} & \multirow[b]{2}{*}{0,17} & \multirow[b]{2}{*}{$p=0,00337$} \\
\hline & wyłącznie prywatnie & $\begin{array}{c}2 \\
2,06 \%\end{array}$ & $\begin{array}{c}3 \\
3,09 \%\end{array}$ & $\begin{array}{c}44 \\
45,36 \%\end{array}$ & $\begin{array}{c}48 \\
49,48 \%\end{array}$ & & & \\
\hline
\end{tabular}


TABELA 3. Podział badanych ze względu na liczbę zachowanych stref podparcia i źródło finansowania leczenia stomatologicznego

\begin{tabular}{|c|c|c|c|c|c|c|}
\hline \multirow{2}{*}{$\begin{array}{l}\text { Zmodyfikowana } \\
\text { klasyfikacja wg Eichnera }\end{array}$} & \multicolumn{6}{|c|}{ Źródło finansowania leczenia stomatologicznego } \\
\hline & $\begin{array}{c}\text { ustugi w ramach } \\
\text { NFZ }\end{array}$ & ustugi prywatne & $\begin{array}{l}\text { ustugi w ramach } \\
\text { NFZ i prywatne }\end{array}$ & $\mathrm{X}^{2}$ Pearsona & R rang & Spearman \\
\hline $\begin{array}{l}\text { Brak stref podparcia } \\
\text { B4, C1, C2, C3 }\end{array}$ & $\begin{array}{c}33 \\
45,21 \% \\
p=0,000001\end{array}$ & $\begin{array}{c}10 \\
10,31 \% \\
p=0,00019\end{array}$ & $\begin{array}{c}26 \\
20,97 \% \\
p=0,38737\end{array}$ & $p=0,000001$ & $-0,17$ & $p=0,00325$ \\
\hline $\begin{array}{l}1 \text { strefa podparcia } \\
\text { B3 }\end{array}$ & $\begin{array}{c}6 \\
8,22 \% \\
p=0,82844\end{array}$ & $\begin{array}{c}7 \\
7,22 \% \\
p=0,49053\end{array}$ & $\begin{array}{c}13 \\
10,48 \% \\
p=0,39754\end{array}$ & $p=0,68123$ & 0,04 & $p=0,49674$ \\
\hline $\begin{array}{l}2 \text { strefy podparcia } \\
\text { B2 }\end{array}$ & $\begin{array}{c}7 \\
9,59 \% \\
p=0,16013\end{array}$ & $\begin{array}{c}19 \\
19,59 \% \\
p=0,09114\end{array}$ & $\begin{array}{c}17 \\
13,71 \% \\
p=0,70419\end{array}$ & $p=0,17561$ & 0,02 & $p=0,69844$ \\
\hline $\begin{array}{l}3 \text { strefy podparcia } \\
\text { B1 }\end{array}$ & $\begin{array}{c}4 \\
5,48 \% \\
p=0,04197\end{array}$ & $\begin{array}{c}15 \\
15,46 \% \\
p=0,23740\end{array}$ & $\begin{array}{c}17 \\
13,71 \% \\
p=0,51288\end{array}$ & $p=0,11693$ & 0,08 & $p=0,16516$ \\
\hline $\begin{array}{l}4 \text { strefy podparcia } \\
A 1, A 2, A 3\end{array}$ & $\begin{array}{c}23 \\
31,51 \% \\
p=0,06196\end{array}$ & $\begin{array}{c}46 \\
47,42 \% \\
p=0,10583\end{array}$ & $\begin{array}{c}51 \\
41,13 \% \\
p=0,92577\end{array}$ & $p=0,11212$ & 0,05 & $p=0,35505$ \\
\hline$x^{2}$ Pearsona & 32,21 & $\mathrm{df}=8$ & & $p=0,0$ & & \\
\hline $\mathrm{R}$ rang Spearman & 0,12 & $t=2,0656$ & & $p=0,0$ & & \\
\hline
\end{tabular}

w szczęce $(34,25 \%$ vs $4,12 \%$ vs $19,35 \%)$, jak i w żuchwie $(23,29 \%$ vs $3,09 \%$ vs $12,10 \%)$. Najwyższy odsetek użytkujących protezy częściowe (w tym protezy szkieletowe) i most lub mosty protetyczne w szczęce $(10,31 \%)$ i w żuchwie $(4,12 \%)$ odnotowano wśród pacjentów korzystających tylko z usług sektora prywatnego. Żaden badany korzystający wyłącznie z usług stomatologicznych w ramach NFZ nie posiadał protezy częściowej i mostu lub mostów protetycznych w żuchwie. Więcej niż jeden most protetyczny zarówno w szczęce, jak i w żuchwie stwierdzono najczęściej u pacjentów korzystających z usług gabinetów prywatnych, a najrzadziej u badanych korzystających wyłącznie z usług NFZ. Żaden pacjent korzystający wyłącznie z usług NFZ nie posiadał powyżej jednego mostu protetycznego w żuchwie (tab. 4).

Jak wynika z danych przedstawionych w tabeli 5, porównując potrzeby leczenia protetycznego braków zębowych ze źródłem finansowania usług stomatologicznych, wykazano zależność istotną statystycznie w szczęce oraz w żuchwie. Uzupełnienia protetycznego bezzębia zarówno w szczęce, jak i w żuchwie najczęściej wymagali pacjenci korzystający wyłącznie z usług stomatologicznych w ramach NFZ, a najrzadziej pacjenci korzystający wyłącznie z leczenia stomatologicznego w gabinetach prywatnych. Należy zauważyć, że w badaniu wykazano znamiennie wyższy odsetek osób bezzębnych wśród badanych korzystających wyłącznie z usług NFZ i znamiennie niższy odsetek osób bezzębnych wśród badanych korzystających wyłącznie z leczenia stomatologicznego w gabinetach prywatnych (tab. 2). Najwyższy odsetek osób wymagających uzupełnienia protetycznego pojedynczego braku zębowego zarówno szczęki, jak i żuchwy wykazano wśród badanych korzystających wyłącznie z usług stomatologicznych gabinetów prywatnych, a najniższy wśród badanych korzystających wyłącznie z usług stomatologicznych w ramach świadczeń gwarantowanych NFZ.

\section{DYSKUSJA}

W Polsce brakuje programów propagujących zdrowie jamy ustnej osób w starszym wieku. Na podstawie raportu Najwyższej Izby Kontroli wartość rynku stomatologicznego w Polsce w 2010 r. osiągnęła 7,1 miliarda zł, z czego jedynie $24 \%$ pochodziło ze środków publicznych. Najwyższa Izba Kontroli negatywnie oceniła brak zapewnienia przez organy administracji publicznej równego dostępu do świadczeń stomatologicznych finansowanych ze środków publicznych. Zwrócono uwagę na fakt, że w 2011 r. jedynie $22 \%$ osób uprawnionych skorzystało z leczenia stomatologicznego w ramach NFZ [9]. W ramach leczenia protetycznego osobom ubezpieczonym NFZ refunduje raz na 5 lat uzupełnienie braków zębowych akrylowymi protezami ruchomymi całkowitymi lub częściowymi z prostymi klamrami doginanymi. W przypadku protez częściowych wymagany jest brak co najmniej 5 zębów w łuku zębowym. Ograniczenia czasowe nie dotyczą jedynie osób po operacyjnym usunięciu nowotworu w obrębie twarzoczaszki. Naprawa protezy przysługuje pacjentowi raz na 2 lata. Narodowy Fundusz Zdrowia nie refunduje leczenia endodontycznego zębów przedtrzonowych oraz trzonowych u dorosłych, nie daje również możliwości leczenia pacjentów protezami śluzówkowo-ozębnowymi i uzupełnieniami stałymi. Nie jest refundowane wykonanie zdjęć pantomograficznych ze wskazań protetycznych (refundacja obejmuje wykonanie zdjęcia pantomograficznego z opisem ze wskazań chirurgicznych bądź periodontologicznych raz na 3 lata). Pacjent ma prawo do refundacji 2 zdjęć wewnątrzustnych w ciągu roku kalendarzowego w połączeniu z innymi świadczeniami gwarantowanymi. Brak jest osobnych świadczeń gwarantowanych w grupie pacjentów starszych [10].

W Niemczech w ramach ubezpieczenia zdrowotnego zwracane są koszty leczenia stomatologicznego związane 
TABELA 4. Podział badanych ze względu na status protetyczny według Światowej Organizacji Zdrowia (WHO) w szczęce i w żuchwie oraz źródło finansowania leczenia stomatologicznego

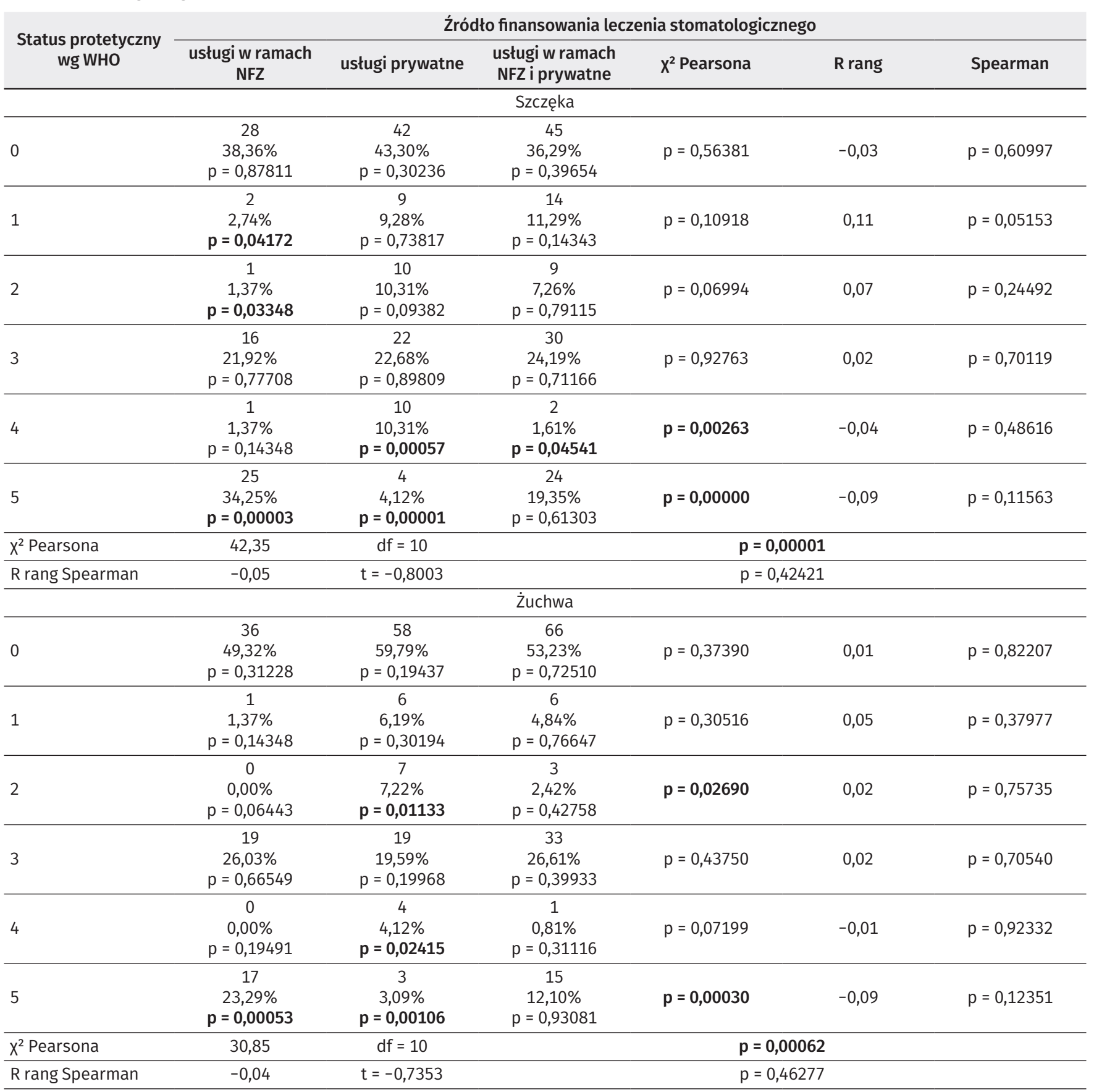

0 - brak uzupełnień protetycznych; 1 - pojedynczy most protetyczny; 2 - więcej niż jeden most protetyczny; 3 - proteza częściowa; 4 - proteza częściowa i most lub mosty protetyczne; 5 - proteza całkowita

z ekstrakcją zęba, niechirurgicznym leczeniem przeciwzapalnym przyzębia, rentgenodiagnostyką, leczeniem endodontycznym oraz zachowawczym zębów (odbudowa amalgamatem bądź kompozytem). Pacjent pokrywa 50\% kosztów leczenia protetycznego obejmującego uzupełnienia ruchome braków zębowych, korony i mosty protetyczne (refundacja nie obejmuje uzupełnień protetycznych typu inlay, koron pełnoceramicznych oraz implantów zębowych). Dodatkowo każdy pacjent zgłaszający się na coroczne wizyty kontrolne uzyskuje o 10\% wyższy zwrot kosztów leczenia. Niemiecki system opieki zdrowotnej zakłada roczne limity wypłat dla lekarzy stomatologów. Jeżeli w roku całkowita kwota finansowania usług stomatologicznych zostaje przekroczona, wówczas wprowadzane są ograniczenia refundacji zabiegów stomatologicznych [11].

W Norwegii koszty leczenia stomatologicznego osób starszych zamieszkujących domy rodzinne pokrywają sami pacjenci. Norweska opieka stomatologiczna finansowana przez państwo dotyczy osób starszych zamieszkujących ośrodki opieki społecznej oraz przewlekle chorych i niepełnosprawnych, dzieci do lat 18 oraz młodych dorosłych w wieku 18-21 lat [12].

System opieki stomatologicznej w Wielkiej Brytanii umożliwia pacjentom skorzystanie z usług gabinetów prywatnych 
TABELA 5. Podział badanych ze względu na potrzeby leczenia protetycznego braków zębowych według Światowej Organizacji Zdrowia (WHO) w szczęce i w żuchwie oraz źródło finansowania leczenia stomatologicznego

\begin{tabular}{|c|c|c|c|c|c|c|}
\hline \multirow{2}{*}{$\begin{array}{c}\text { Potrzeby leczenia } \\
\text { protetycznego } \\
\text { braków zębowych } \\
\text { wg WHO }\end{array}$} & \multicolumn{6}{|c|}{ Źródło finansowania leczenia stomatologicznego } \\
\hline & $\begin{array}{c}\text { ustugi w ramach } \\
\text { NFZ }\end{array}$ & ustugi prywatne & $\begin{array}{l}\text { usługi w ramach } \\
\text { NFZ i prywatne }\end{array}$ & $x^{2}$ Pearsona & R rang & Spearman \\
\hline \multicolumn{7}{|c|}{ Szczęka } \\
\hline 0 & $\begin{array}{c}27 \\
36,99 \% \\
p=0,66720\end{array}$ & $\begin{array}{c}35 \\
36,08 \% \\
p=0,45457\end{array}$ & $\begin{array}{c}53 \\
42,74 \% \\
p=0,27653\end{array}$ & $p=0,54926$ & 0,06 & $p=0,34505$ \\
\hline 1 & $\begin{array}{c}3 \\
4,11 \% \\
p=0,06913\end{array}$ & $\begin{array}{c}15 \\
15,46 \% \\
p=0,01491\end{array}$ & $\begin{array}{c}10 \\
8,06 \% \\
p=0,46662\end{array}$ & $p=0,03402$ & 0,02 & $p=0,73447$ \\
\hline 2 & $\begin{array}{c}15 \\
20,55 \% \\
p=0,96117\end{array}$ & $\begin{array}{c}25 \\
25,77 \% \\
p=0,13598\end{array}$ & $\begin{array}{c}21 \\
16,94 \% \\
p=0,16854\end{array}$ & $p=0,27424$ & $-0,05$ & $p=0,35688$ \\
\hline 3 & $\begin{array}{c}11 \\
15,07 \% \\
p=0,21865\end{array}$ & $\begin{array}{c}20 \\
20,62 \% \\
p=0,86864\end{array}$ & $\begin{array}{c}28 \\
22,58 \% \\
p=0,35825\end{array}$ & $p=0,43958$ & 0,07 & $p=0,23103$ \\
\hline 4 & $\begin{array}{c}17 \\
23,29 \% \\
p=0,00004\end{array}$ & $\begin{array}{c}2 \\
2,06 \% \\
p=0,00089\end{array}$ & $\begin{array}{c}12 \\
9,68 \% \\
p=0,67939\end{array}$ & $p=0,00004$ & $-0,13$ & $p=0,02951$ \\
\hline$x^{2}$ Pearsona & 28,16 & $\mathrm{df}=8$ & \multicolumn{4}{|c|}{$p=0,00044$} \\
\hline $\mathrm{R}$ rang Spearman & $-0,07$ & $t=-1,220$ & \multicolumn{4}{|c|}{$p=0,22362$} \\
\hline \multicolumn{7}{|c|}{ Żuchwa } \\
\hline 0 & $\begin{array}{c}21 \\
28,77 \% \\
p=0,45497\end{array}$ & $\begin{array}{c}32 \\
32,99 \% \\
p=0,86178\end{array}$ & $\begin{array}{c}42 \\
33,87 \% \\
p=0,62565\end{array}$ & $p=0,74917$ & 0,04 & $p=0,49726$ \\
\hline 1 & $\begin{array}{c}4 \\
5,48 \% \\
p=0,17455\end{array}$ & $\begin{array}{c}14 \\
14,43 \% \\
p=0,04421\end{array}$ & $\begin{array}{c}10 \\
8,06 \% \\
p=0,46662\end{array}$ & $p=0,11052$ & 0,01 & $p=0,89880$ \\
\hline 2 & $\begin{array}{c}20 \\
27,40 \% \\
p=0,33363\end{array}$ & $\begin{array}{c}34 \\
35,05 \% \\
p=0,42704\end{array}$ & $\begin{array}{c}40 \\
32,26 \% \\
p=0,92862\end{array}$ & $p=0,56836$ & 0,03 & $p=0,61209$ \\
\hline 3 & $\begin{array}{c}13 \\
17,81 \% \\
p=0,90444\end{array}$ & $\begin{array}{c}14 \\
14,43 \% \\
p=0,35450\end{array}$ & $\begin{array}{c}24 \\
19,35 \% \\
p=0,43743\end{array}$ & $p=0,62689$ & 0,03 & $p=0,63362$ \\
\hline 4 & $\begin{array}{c}15 \\
20,55 \% \\
p=0,00005\end{array}$ & $\begin{array}{c}3 \\
3,09 \% \\
p=0,01481\end{array}$ & $\begin{array}{c}8 \\
6,45 \% \\
p=0,21733\end{array}$ & $p=0,00018$ & $-0,16$ & $p=0,00624$ \\
\hline$x^{2}$ Pearsona & 21,66 & $\mathrm{df}=8$ & & & & \\
\hline $\mathrm{R}$ rang Spearman & $-0,08$ & $t=-1,398$ & & & & \\
\hline
\end{tabular}

lub z usług w ramach Narodowej Służby Zdrowia (National Health System - NHS). Osoby starsze nie są zwolnione z opłat związanych z zabiegami stomatologicznymi (darmowe leczenie przysługuje osobom hospitalizowanym oraz pacjentom o niskich dochodach). W ostatnich badaniach narodowych przeprowadzonych w Wielkiej Brytanii stwierdzono, że 2/3 populacji osób dorosłych korzysta z ubezpieczenia zdrowotnego $w$ ramach NHS, a 1/3 populacji posiada prywatne ubezpieczenie zdrowotne. Wykazano, że 20\% pacjentów ma trudności w dostępie do gabinetów stomatologicznych umożliwiających korzystanie z usług stomatologicznych w ramach NHS. Należy zauważyć, że pacjenci korzystający z systemu NHS mogą liczyć na częściowy zwrot kosztów leczenia stomatologicznego, w tym leczenia protetycznego uzupełnieniami ruchomymi i stałymi [13].
System finansowania opieki stomatologicznej w USA nie zakłada osobnych świadczeń gwarantowanych dla osób starszych zamieszkujących domy rodzinne. Świadczenia stomatologiczne w USA refundowane są w ramach Programu Ubezpieczeń Społecznych (The Social Security Program), którego częścią jest program Medicare obejmujący osoby powyżej 65. r.ż. oraz osoby niepełnosprawne poniżej 65. r.ż. W ramach programu Medicare jedynie osoby starsze o niskim statusie ekonomicznym mogą skorzystać z dodatkowej refundacji świadczeń stomatologicznych [14]. Za ochronę zdrowia pacjentów starszych w USA odpowiadają jeszcze dwa federalne programy zdrowotne: The Post Eligibility Treatment of Income program (PETI) oraz the Old Age Pension Program [15].

Należy zauważyć, że żaden z programów polityki zdrowotnej porównywanych państw europejskich oraz USA nie refunduje 
pełnego leczenia stomatologicznego osób starszych. Finansowanie kosztów leczenia stomatologicznego osób starszych ze środków publicznych jest niewystarczające zarówno w Polsce, jak i w wybranych krajach Europy i świata.

\section{WNIOSKI}

W badaniu stwierdzono istotnie gorszy stan zdrowia jamy ustnej u pacjentów deklarujących korzystanie wyłącznie z usług stomatologicznych w ramach świadczeń gwarantowanych NFZ w porównaniu do badanych korzystających wyłącznie z usług gabinetów prywatnych. Dostępność, organizacja opieki zdrowotnej oraz poziom finansowania leczenia stomatologicznego wpływają na umożliwienie osobom starszym korzystania z usług gabinetów stomatologicznych. Osoby starsze powinny być objęte celowaną opieką zdrowotną. Monitorowanie statusu protetycznego oraz potrzeb leczenia protetycznego braków zębowych wśród osób starszych jest niezbędne dla tworzenia oraz rozwoju istniejących programów profilaktycznych i leczniczych w tej grupie wiekowej.

\section{PIŚMIENNICTWO}

1. Rutkowska L. Trwanie życia w 2012 r. Warszawa: Główny Urząd Statystyczny, Zakład Wydawnictw Statystycznych; 2013. p. 14-7.
2. Prognoza ludności Polski na lata 2008-2035. Warszawa: Główny Urząd Statystyczny; 2008. p. 2 (tabl. 2).

3. Population projections 2010-2060. [online]. Eurostat, 2011. http:// ec.europa.eu/eurostat (15.12.2015).

4. National Institute on Aging: Rising numbers of the oldest old. In: Why Population aging matters: A global perspective. [online]. 2007, 10-15. http://www.nia.nih.gov/publication (10.06.2015).

5. Kunert J, Brauman-Furmanek S. Problemy leczenia zachowawczego pacjentów geriatrycznych. Dent Forum 2013;1:83-9.

6. Żołędowski C. Starzenie się ludności - Polska na tle Unii Europejskiej. Problemy Polityki Społecznej. Studia i dyskusje 2012:29-43. problemypolitykispolecznej.pl/images/czasopisma/17/PPS\%2017-Żołędowski. pdf (10.06.2015).

7. Pawlik A. Gerostomatologia - nowe wyzwanie dla stomatologów. Twój Prz Stomatol 2007;10:62-3.

8. Petersen PE, Kandelman D, Arpin S, Ogawa H. Global oral health of older people-Call for public health action. Community Dent Health 2010;27:257-68.

9. Najwyższa Izba Kontroli: Dostępność i finansowanie opieki stomatologicznej ze środków publicznych. Informacja o wynikach kontroli. [online]. Warszawa, 2013, 6-9. www.nik.gov.pl (10.06.2015).

10. Rozporządzenie Ministra Zdrowia z dnia 6 listopada 2013 r. w sprawie świadczeń gwarantowanych z zakresu leczenia stomatologicznego (Dz.U. 2013 r., poz. 1462)

11. Nitschke I. Geriatric oral health issues in Germany. Int Dent J 2001;51:235-46.

12. Kravitz AS, Bullock A, Cowpe J, Barnes E. Manual of dental practice 2014, Norway. Council of European Dentists. EU Manual of Dental Practice. Ed. 5. Wales (UK): Cardiff University; 2014. https://www.omd.pt/europa/ cedmanual/2014/2014/ced-manual-noruega.pdf (8.11.2015).

13. McGrath C, Bedi R, Dhawan N. Who has difficulty in registering with an NHS dentist? A national survey. Br Dent J 2001;191:682-5.

14. An oral health America special grading project: The oral health of older Americans. Chicago; Oral Health America, 2003.

15. Berkey D, Berg R. Geriatric oral health issues in the United States. Int Dent J 2001;51: 254-64. 